\title{
Insulin-like Growth Factor-I and Piglet Intestinal Development ${ }^{\star} \dagger$
}

\author{
S. M. Donovan, ${ }^{1}$ J. L. Hartke, ${ }^{1}$ M. H. Monaco, ${ }^{1}$ and M. B. Wheeler ${ }^{2,3}$ \\ ${ }^{1}$ Division of Nutritional Sciences, ${ }^{2}$ Department of Animal Sciences, \\ and ${ }^{3}$ Beckman Institute for Advanced Science and Technology, \\ University of Illinois, Urbana 61801
}

\begin{abstract}
Porcine milk contains hormones and growth factors that stimulate piglet intestinal growth and development. Milk-borne insulin-like growth-factor-I (IGF-I) has received considerable attention. In swine, IGF-I concentrations range from 0.10 to $0.4 \mathrm{mg} / \mathrm{L}$ in colostrum and approximately 0.01 to $0.04 \mathrm{mg} / \mathrm{L}$ in mature milk. Two experimental approaches have been utilized to investigate the role of orally administered IGF-I in neonatal intestinal development. In the first approach, piglets were reared on sow milk replacer formulas containing recombinant human IGF-I (rhIGF-I) at concentrations of 0.1 to $12 \mathrm{mg} / \mathrm{L}$. The advantage of this approach is that specific effects of IGF-I can be assessed in the absence of other bioactive components, changes in milk composition, and other environmental factors. However, the applicability to swine production is limited. A second approach has been to develop transgenic mice or swine that overexpress IGF-I in milk under the direction of promoter regulatory elements of milk proteins to result in animals experiencing mammary specific overexpression of IGF-I during lactation. Herein, the effect of orally administered IGF-I on neonatal intestinal development in artificial rearing studies, as well as studies utilizing transgenic overexpression of IGF-I in milk, was reviewed. Both rhIGF-I in formula or transgenic IGF-I overexpression increased villus growth and disaccharidase activity; however, these effects were primarily observed late in the suckling period (d 21 postpartum) in piglets suckling IGF-I transgenic sows. We speculate that piglets suckling IGF-I transgenic sows may have improved intestinal health during the weaning transition.
\end{abstract}

(Key words: IGF-I, intestine, lactase, piglet, transgenic)

Received September 9, 2003.

Accepted November 24, 2003.

Corresponding author: S. M. Donovan; e-mail: sdonovan@uiuc.edu.

*Presented at a symposium titled "Intestinal development-Colostrum," at the ADSA-ASAS Joint Annual Meeting, June 2003, Phoenix, AZ.

†Supported by the Cooperative Research Council, Education and Extension Service, USDA under project No. 00-35206 and the Illinois Council for Food and Agricultural Research Sentinel Program.
Abbreviation key: BB-LPH = insertion of the active enzyme into the brush border membrane, IGFBP = insulin-like growth factor binding proteins, $\mathbf{L P H}=$ lactase phlorizin hydrolase, $\mathbf{N a}^{+}-\mathbf{K}^{+}$-ATPase $=$sodium potassium adenosine triphosphatase, proLPH $=$ precursor isoforms of lactase, triphosphatase, $\mathbf{T g}=$ transgenic.

\section{INTRODUCTION}

Upon ingestion of colostrum or milk, the porcine neonatal intestine undergoes rapid growth and development. Widdowson et al. (1976) reported that feeding piglets colostrum for the first $24 \mathrm{~h}$ postpartum resulted in a $61 \%$ increase in intestinal mass compared with piglets fed water. Although a portion of this increase in intestinal intestinal mass can be attributed to macromolecular absorption of colostral immunoglobulin (Burrin et al., 1992), the concurrent increases in intestinal length and DNA content suggested that cellular proliferation was also occurring. These observations were extended by Burrin et al. (1992, 1994, 1995), who demonstrated that feeding colostrum or milk for the first 6 $\mathrm{h}$ postpartum increased jejunal protein synthesis rate by $300 \%$ compared with piglets fed water for the same period of time. A limitation of these studies was the use of water-fed piglets as the comparison group. However, the trophic effects of colostrum were still apparent when comparisons were made with animals fed a milk replacer formula with a nutrient composition similar to that of colostrum (Burrin et al., 1995). In that study, skeletal muscle and jejunal protein synthesis rates were higher in piglets fed colostrum, indicating that either colostral components themselves or endogenous factors that are released in response to colostrum intake may mediate growth of both the intestine and tissues outside the gastrointestinal tract (Burrin et al., 1995).

It has been proposed that hormones and growth factors present in colostrum and milk may be in part responsible for the trophic effects observed in response to feeding (Donovan and Odle, 1994; Blum and Baumrucker, 2002). The complex nature of the growth factor composition of colostrum and milk, including the presence of factors that could conceivably potentiate or inhibit each other's actions, has limited our ability to 
Table 1. Studies investigating oral administration of recombinant human IGF-I on piglet intestinal development

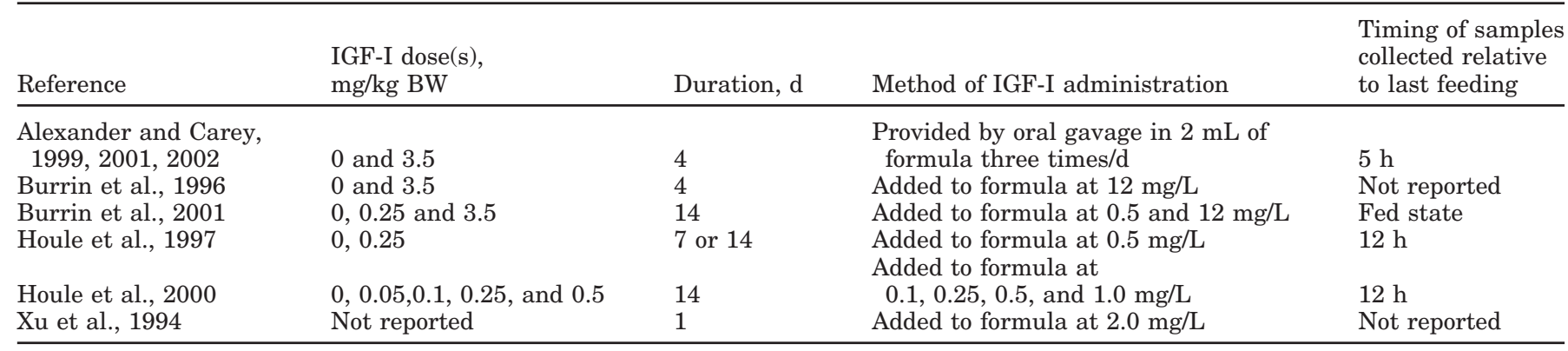

define the roles of individual milk growth factors on neonatal intestinal development. Thus, a number of investigators have taken the approach of supplementing recombinant growth factors to milk replacer formulas to delineate the roles of specific growth factors in milk in intestinal development (Table 1). A second approach has been to develop transgenic animals that overexpress a single growth factor in milk and assess the intestinal development of neonates suckling the transgenic animals (Burrin et al., 1999). The growth factor that has received a considerable amount of study in this regard is IGF-I.

\section{Insulin-Like Growth Factor-I}

Insulin-like growth factor-I is a $7.5-\mathrm{kDa}$ single-chain peptide that belongs to a family of growth factors that includes IGF-II, insulin, and relaxin. The IGF-I AA sequence is identical in human, porcine, ovine, and bovine species (Tavakkol et al., 1988). Insulin-like growth factor-I exerts its actions primarily through the type-I IGF receptor (Oh et al., 1993), which has been identified in porcine mammary gland (Lee et al., 1993) and intestine (Morgan et al., 1996). Insulin-like growth factor-I and IGF-II in serum and milk are found almost entirely in association with IGF-binding proteins (IGFBP). The IGFBP prolong the circulating half-life of IGF, transport IGF from the extracellular space into tissues, and localize IGF to specific cell types and tissues (Cohick, 1998). In addition, IGFBP exert IGF-independent effects on tissue growth (Hwa et al., 1999). Six highaffinity IGFBP (IGFBP-1 through -6) have been cloned and sequenced (Hwa et al., 1999). Porcine serum IGFBP profiles are similar to those of humans (Donovan et al., 1994). A second category of IGFBP-related proteins, which bind IGF-I and -II with lower affinity than IGFBP and also bind insulin, have been recently identified (Hwa et al., 1999).

\section{IGF-I in the Mammary Gland and Milk}

Insulin-like growth factor-I is a regulator of mammary growth and differentiation (Cohick, 1998). It stim- ulates cellular growth and DNA synthesis in cultured bovine (Shamay et al., 1988) and ovine (Winder et al., 1989) mammary tissues. In addition, IGF-I is an inhibitor of mammary apoptosis (Neuenschwander et al., 1996; Rosfjord and Dickson, 1999). Insulin-like growth factor-I is also thought to mediate a portion of the effects of $\mathrm{GH}$ on lactation (Cohick, 1998). Administration of GH to lactating animals increases circulating IGF-I concentrations, and the presence of IGF receptors within the mammary gland would provide a site of action for the peptide (Cohick 1998). Indeed, a galactopoietic effect of circulating IGF-I was demonstrated in goats infused with IGF-I (Prosser et al., 1990), although a similar effect has not been shown in cattle (Cohick, 1998).

Insulin-like growth factor-I is present in the milk of all mammals and is higher in colostrum than in mature milk (Donovan and Odle, 1994). Insulin-like growth factor-I concentrations range from 0.7 to $0.10 \mathrm{mg} / \mathrm{L}$ in porcine colostrum and from 0.01 to $0.04 \mathrm{mg} / \mathrm{L}$ in mature milk (Donovan et al., 1994). Insulin-like growth factorII is also present in porcine colostrum and milk. Colostral IGF-II concentrations range from 0.10 to $0.165 \mathrm{mg} /$ $\mathrm{L}$ and from 0.01 to $0.04 \mathrm{mg} / \mathrm{L}$ in mature milk (Donovan et al., 1994). Despite the high concentrations of IGF-II in porcine milk, only one study to date has assessed the role of orally administered IGF-II in piglet intestinal development (Xu et al., 1994). In addition, porcine milk contains IGFBP-1, -2, -3, and -4 (Donovan et al., 1994). How milk IGFBP modulate the actions of IGF-I and II within the neonatal intestine is unknown. A recent study suggests that association of IGF-I with IGFBP3 does not protect IGF-I from in vitro digestion by adult rat gastrointestinal secretions (Xian et al., 1995).

\section{Enterally Administered Recombinant Human IGF-I or -II and Piglet Intestinal Development}

Both IGF-I and IGF-II receptors are present throughout the intestine (Heinz-Erian et al., 1991; Morgan et al., 1996). Both receptors are more concentrated on the proliferative cells within the crypt vs. the fully differen- 
tiated cells located on the villus, supporting a role in intestinal growth. In addition, receptor binding is higher in newborn animals and declines with age. Since the mid-1990s, over 20 studies have been performed in adult and neonatal rats, fetal sheep, and suckling piglets to investigate the impact of orally or systemically administered IGF-I on intestinal development (MacDonald, 1999). Beneficial effects of orally administered IGF-I have been reported in neonatal piglets (Table 1). In these studies, the IGF-I doses administered ranged from physiological doses of 0.1 to $1.0 \mathrm{mg} / \mathrm{kg}$ for $14 \mathrm{~d}$ (Houle et al., 1997, 2000) to a supraphysiological dose of $3.5 \mathrm{mg} / \mathrm{kg}$ for $4 \mathrm{~d}$ (Burrin et al., 1996, 2001; Alexander and Carey, 1999, 2001, 2002). In general, no effects of oral IGF-I on serum IGF-I concentrations, overall BW, or growth of tissues other than the intestine were reported. The lack of systemic effects supports our observation that milk-borne IGF-I is absorbed only to a limited extent by the neonatal piglet (Donovan et al., 1997). Insulin-like growth hormone-I is rapidly degraded within the adult gastrointestinal tract (Xian et al., 1995; Rao et al., 1998), but it appears to survive digestion and exert effects within the neonatal intestine. Rao et al. (1998) found that the proteolytic degradation of both peptides was less when the peptides were exposed to luminal secretions from neonatal vs. adult rats (Rao et al., 1998). In addition, IGF-II was more resistant to proteolytic degradation than was IGF-I (Rao et al., 1998).

Summarized in Table 2 are the results of the studies in which recombinant human IGF-I has been administered to neonatal piglets. Not all studies have shown similar effects of oral IGF-I on intestinal development, even when a similar dose of IGF-I was administered (Table 1). For example, studies conducted by Alexander and Cary $(1999,2001,2002)$ reported no effect on mucosal growth despite the fact that the IGF-I dose $(3.5 \mathrm{mg} /$ $\mathrm{kg} \mathrm{BW}$ ) and timing of exposure (4 d) was the same as in Burrin et al. (1996). However, the manner in which the IGF-I was administered differed between the two laboratories. Alexander and Cary (1999, 2001, 2002) administered the IGF-I dose by oral gavage three times daily in $2 \mathrm{~mL}$ of formula. In contrast, Burrin et al. (1996) dissolved the IGF-I in the full volume of formula, which was the same approach used by Houle et al. (1997, 2000). It is possible that the high concentration of IGF-I administered by oral gavage led to an internalization of IGF-I receptors and a less sustained response to IGF-I than would be achieved by a more continuous exposure to lower concentrations of IGF-I in the formula. Unfortunately, IGF-I receptor binding was not assessed in the studies by either Burrin (1996) or Alexander and Cary (1999, 2001, 2002). Another possibility for the differences observed between the studies is the timing of sample collection relative to the feeding (Table 1). We have preliminary data showing that short-term food restriction (6 to $12 \mathrm{~h}$ ) increases villus height as much as $40 \%$ relative to samples obtained in the fed state (Harke et al., 2003). Thus, postabsorptive state must be considered when comparing the studies.

Orally administered IGF-I has been shown to increase intestinal weight, protein content, DNA synthesis and content, villus morphology, and lactase activity (Xu et al., 1994; Burrin et al., 1996; Houle et al., 1997; 2000) (Table 2). In general, supraphysiological doses of IGF-I appear to exert greater trophic effects (Burrin et al., 1996), whereas lower doses have modest effects on villus growth and DNA synthesis (Houle et al., 1997, 2000). Enterally administered IGF-I also increases several markers of intestinal differentiated function, including lactase activity (Houle et al., 1997, 2000) and nutrient transport (Alexander and Carey, 1999, 2001, 2002) (Table 2). Lactase activity was significantly higher throughout the small intestine in piglets fed formula containing 0.5 to $1.0 \mathrm{mg} / \mathrm{L}(0.25$ to $0.5 \mathrm{mg} / \mathrm{kg}$ BW) compared with formula alone (Houle et al., 1997, 2000). Lactase activity was numerically increased within the intestine of piglets fed formula containing as little as $0.1 \mathrm{mg}$ of IGF-I/L $(0.05 \mathrm{mg} / \mathrm{kg} \mathrm{BW})$. At the cellular level, lactase synthesis and activity is subject to regulation at the level of transcription, translation or post-translational processing. In piglets fed formula containing $1.0 \mathrm{mg}$ IGF-I/L, jejunal lactase mRNA expression was greater than that observed in piglets fed formula alone, suggesting that IGF-I may regulate lactase synthesis at the level of transcription (Houle et al., 2000).

In the pig, several precursor isoforms of lactase (proLPH) are produced prior to the final insertion of the active enzyme into the brush border membrane (BB-LPH). The processing of the proLPH includes glycosylation and proteolytic cleavage. In piglets, $<100 \%$ of proLPH appears in the brush border membrane (Dudley et al., 1998). To investigate the effect of oral IGF-I on the synthesis of proLPH and its efficiency of transfer to the brush border membrane, Burrin et al. (2001) utilized a stable isotope protocol involving an overlapping infusion of six AA isotopes that allows for detailed kinetic analysis within a single sample (Dudley et al., 1998). Piglets were fed a formula containing 0.5 or $12 \mathrm{mg}$ of IGF-I/L for $14 \mathrm{~d}$. Oral IGF-I decreased the synthesis of proLPH, but increased the synthesis of BBLPH in the ileum. Because the rate of proLPH synthesis was not increased by IGF-I, the increase in BB-LPH synthesis reflected a two- to threefold higher efficiency of processing newly synthesized pro-LPH to BB-LPH in piglets fed formula with IGF-I vs. formula alone (Burrin et al., 2001). It was postulated that the increased 
Table 2. Effects of oral administration of recombinant human IGF-I on piglet intestinal development

\begin{tabular}{|c|c|c|c|c|c|c|}
\hline Citation & $\begin{array}{l}\text { Intestinal weight } \\
\text { and length }\end{array}$ & Protein and DNA & Histomorphology & $\begin{array}{l}\text { Enterocyte } \\
\text { proliferation }\end{array}$ & $\begin{array}{l}\text { Lactase activity, } \\
\text { mRNA expression, } \\
\text { or synthesis }\end{array}$ & $\begin{array}{l}\text { Nutrient transport and } \\
\text { electrophysiological } \\
\text { measures }\end{array}$ \\
\hline Alexander and Carey, 1999 & No effect & No effect & No effect & Not assessed & No effect & $\begin{array}{l}\text { Increased basal Isc }{ }^{1} \\
\text { and } \mathrm{PD}^{2} ; \\
\text { Increased } \mathrm{Na}^{+} \text {-dependent } \\
\text { Glc and } \mathrm{Ala} \text { transport }\end{array}$ \\
\hline Alexander and Carey, 2001 & No effect & No effect & No effect & Not assessed & No effect & $\begin{array}{l}\text { Increased } \mathrm{Na}^{+} \text {, } \\
\mathrm{K}^{+} \text {- ATPase activity; } \\
\text { increased basal Isc, PD, } \\
\text { and } \mathrm{Na}^{+} \text {-dependent Glc } \\
\text { transport in response to } \\
\text { acute IGF-I exposure }\end{array}$ \\
\hline Alexander and Carey, 2002 & Not assessed & Not assessed & Not assessed & Not assessed & Not assessed & $\begin{array}{l}\text { Increased basal Isc } \\
\text { and PD; increased } \\
\mathrm{Na}^{+} \text {-dependent } \\
\text { Gln transport }\end{array}$ \\
\hline Burrin et al., 1996 & $\begin{array}{l}\text { Increased weight; } \\
\text { no effect on length }\end{array}$ & $\begin{array}{l}\text { Increased jejunal } \\
\text { and ileal protein and DNA }\end{array}$ & $\begin{array}{l}\text { Increased jejunal } \\
\text { and ileal villus height }\end{array}$ & Not assessed & Not assessed & Not assessed \\
\hline Burrin et al., 2001 & No effect & No effect & No effect & Not assessed & $\begin{array}{l}\text { Increased efficiency } \\
\text { of processing } \\
\text { from precursor to } \\
\text { mature form }\end{array}$ & Not assessed \\
\hline Houle et al., 1997 & No effect & & Increased ileal villus height & Not assessed & Increased activity & Not assessed \\
\hline Houle et al., 2000 & No effect & $\begin{array}{l}\text { Increased intestinal DNA, } \\
\text { but not protein }\end{array}$ & $\begin{array}{l}\text { Increased jejunal villus } \\
\text { height and crypt death }\end{array}$ & $\begin{array}{l}\text { Increased BrdU } \\
\text { incorporation }\end{array}$ & $\begin{array}{l}\text { Increased activity } \\
\text { and mRNA expression }\end{array}$ & Not assessed \\
\hline Xu et al., 1994 & $\begin{array}{l}\text { No effect on intestine; } \\
\text { pancreas weight } \\
\text { was increased }\end{array}$ & $\begin{array}{l}\text { No effect on intestine; } \\
\text { increased stomach } \\
\text { and pancreas DNA content }\end{array}$ & No effect & $\begin{array}{l}\text { Increased BrdU } \\
\text { incorporation }\end{array}$ & Not assessed & Not assessed \\
\hline
\end{tabular}

Isc $=$ Short circuit current

${ }^{2} \mathrm{PD}=$ Potential difference. 
efficiency of processing was a consequence of a suppression of intracellular proteolysis in the IGF-I-treated piglets.

A recent series of studies by Alexander and Carey (1999, 2001, 2002) suggested that oral IGF-I might also improve nutrient absorptive function within the piglet small intestine. Piglets receiving oral IGF-I at $3.5 \mathrm{mg} /$ $\mathrm{kg}$ for $4 \mathrm{~d}$ had significantly increased net $\mathrm{Na}^{+}$and $\mathrm{Cl}^{-}$ transport. Tissues mounted in Ussing chambers also exhibited increased total ion transport and active ion transport (Alexander and Carey 1999, 2002). There was greater $\mathrm{Na}^{+}$-dependent glucose, glutamine and alanine transport in the intestines of piglets fed formula with IGF-I (Alexander and Carey (1999, 2002). The increases in nutrient transport were independent of changes in mucosal mass or surface area (Alexander and Carey 1999, 2002). The protein abundance of the sodiumlinked glucose transporter was similar in control and IGF-I treated piglets, indicating that the mechanism of action was not via increased number of glucose transporters (Alexander and Carey, 2001).

Small intestinal sodium-potassium adenosine triphosphatase $\left(\mathbf{N a}^{+}-\mathbf{K}^{+}\right.$-ATPase $)$activity was higher in piglets receiving IGF-I, although no difference in $\mathrm{Na}^{+}-$ $\mathrm{K}^{+}$-ATPase protein abundance was observed (Alexander and Carey, 2001). The activity of $\mathrm{Na}^{+}-\mathrm{K}^{+}$-ATPase on the basolateral surface of intestinal epithelial cells is thought to "drive" the transport of $\mathrm{Na}^{+}$and $\mathrm{Na}^{+}-$ coupled nutrient transport on the apical surface of the cells. The increases in $\mathrm{Na}^{+}-\mathrm{K}^{+}$-ATPase activity and $\mathrm{Na}^{+}-$ coupled glucose transport were abolished by co-incubating the tissues with wortmannin to inhibit the phosphatidylinositol 3-kinase signaling cascade. These data implicate that IGF-I signaling through enterocyte type-I IGF receptor is critical for IGF-I-induced nutrient uptake (Alexander and Carey, 2001).

\section{Mammary-Specific Overexpression of IGF-I}

Previous researchers have utilized the promoter and regulatory elements of milk proteins to develop transgenic rabbits and mice that overexpress IGF-I in milk (Hadsell et al., 2002). Brem et al. (1994) used $\alpha_{\sigma 1^{-}}$ casein to drive the expression of human IGF-I in rabbits and achieved very high levels of expression (approximately $1 \mathrm{~g}$ of IGF-I/L) and elevated milk IGFBP-2 concentrations. Milk yield was increased by approximately $10 \%(P=0.08)$, although milk protein content was not affected (Wolf et al., 1997). Subsequent studies with this line of transgenic rabbits demonstrated that IGFI production was stable over 6 generations, increased with parity, and was greater in homozygous than in heterozygous animals (Zinovieva et al., 1998). Animals did not exhibit clinical symptoms of altered function or pathology of the mammary gland, although detailed examinations were not performed (Wolf et al., 1997). Two groups have developed transgenic mice using the promoter elements of whey acidic protein to drive the expression of human IGF-I (LeRoith et al., 1995; Neuenschwander et al., 1996) or the IGF-I analog des(13) IGF-I (Hadsell et al., 1996). Insulin-like growth factor-I overexpression inhibited apoptosis and altered mammary gland histology during involution so as to maintain lobular-alveolar structures that were involuting in control glands (Neuenschwander et al., 1996). Although involution was delayed, no cytologic abnormalities or neoplastic features were seen in IGF-I transgenic (Tg) mice (Neuenschwander et al., 1996). The mammary gland of mice overexpressing des(1-3) IGF-I also demonstrated incomplete involution. Additionally, distinct alterations in mammary structure were noted including ductile hypertrophy, increased deposition of collagen and loss of secretory lobules (Hadsell et al., 1996). Increased IGFBP-2 expression was also observed in $\mathrm{Tg}$ animals (Hadsell et al., 1996; Neuenschwander et al., 1996). However, des(1-3) IGFI does not bind to low-molecular-weight IGFBP, including IGFBP-2 (Ballard et al., 1996). Therefore, it is likely that the upregulation of IGFBP-2 in response to IGFI overexpression modulates the bioactivity of IGF-I, but not bioactivity of des(1-3) IGF-I, so that mammary hypertrophy and structural alterations result (Hadsell et al., 1996).

Our group developed Tg swine that overexpress IGFI in milk under the control of the $5^{\prime}$-regulatory elements of the bovine $\alpha$-LA gene (Donovan et al., 2001) to investigate how IGF-I overexpression affects swine mammary gland development and the intestinal development of piglets. The $\alpha$-LA/IGF-I gene construct was designed by inserting exon 4 of the human IGF-I gene, which contains the coding sequence for the mature peptide into exon 1 of a bovine $\alpha$-LA gene construct (Bleck et al., 1998; Donovan et al., 2001). The protein product of the human IGF-I gene is identical to that of the porcine IGF-I gene (Tavakkol et al., 1988). The IGF-I content of colostrum produced by IGF-I Tg sows ranged from 0.6 to $1.4 \mathrm{mg} / \mathrm{L}$, compared with $0.15 \mathrm{mg} / \mathrm{L}$ in milk from full-sib non-Tg sows. The IGF-I content of mature milk produced by IGF-I Tg sows was maintained at approximately $0.6 \mathrm{mg} / \mathrm{L}$ throughout lactation, which was approximately 60 -fold higher than the milk IGF-I content of non-Tg sows (Donovan et al., 2001). Consistent with previous studies (Hadsell et al., 1996; Neuenschwander et al., 1996), mammary IGF-I overexpression increased milk IGFBP. The primary IGFBP that was increased in the milk of IGF-I Tg sows was immunologically identified as IGFBP-2. The IGFBP-5 was also elevated in the milk produced by IGF-I Tg 
sows. Flint et al. (2000) reported that mammary IGFBP-5 expression increases during weaning and involution and proposed that IGFBP-5 functions to sequester IGF-I from its receptor, thereby allowing for the initiation of involution. Supporting this hypothesis, mammary apoptosis $4 \mathrm{~d}$ postweaning, assessed by the terminal deoxynucleotidyl transferase biotin-UTP nick and labeled assay, was lower in IGF-I Tg than in non-Tg sows (Monaco et al., 2003). We are currently assessing whether the increases in IGFBP-2 and -5 observed in the milk of the IGF-I Tg sows was produced within the mammary gland or was transferred from maternal circulation. In either case, the increased presence of IGFBP within the mammary gland of IGF-I Tg sows likely modulated IGF-I bioactivity.

\section{Intestinal Development of Neonates Suckling des(1-3) human IGF-I Transgenic Mice}

Using the des(1-3) human IGF-I transgenic mice developed by Hadsell et al. (1996), Burrin et al. (1999) tested the hypothesis that chronic ingestion of milk with increased concentrations of des(1-3) human IGFI stimulates gastrointestinal growth and development of suckling mice. Pups were allowed to suckle either des(1-3) human IGF-I Tg dams or non-Tg dams. Milk des(1-3) IGF-I concentrations ranged from 11.9 to 68.8 $\mathrm{mg} / \mathrm{L}$ (values 40 - to 200 -fold higher than for native mouse milk). Blood and tissue samples were collected on $\mathrm{d} 4,8,12,16$, and 29 postpartum. Despite the extremely high milk des(1-3) IGF-I concentrations, BW gain or serum IGF-I concentrations were similar in pups suckling des(1-3) IGF-I Tg and non-Tg dams. Small intestinal weight, protein and DNA content were greater on d 8 and 16 in pups suckling des(1-3) IGF-I $\mathrm{Tg}$ dams vs. non-Tg dams. The fractional rate of protein synthesis in the small intestine was also greater in pups suckling des(1-3) IGF-I Tg dams on d 8. Total intestinal lactase activity tended $(P<0.1)$ to be higher on $\mathrm{d} 8$ and 12 of lactation and total intestinal sucrase activity was greater $(P<0.05)$ on $d 16$ in pups suckling des(1-3) IGF-I Tg dams vs. non-Tg dams. Although some significant differences were observed between pups suckling des(1-3) IGF-I Tg and non-Tg dams, the authors concluded that hypersecretion of des(1-3) IGFI into milk had limited effects on mouse pup intestinal growth and maturation (Burrin et al., 1999).

There are several potential explanations for the limited intestinal response in this model. First, chronic ingestion of a clearly pharmacological dose of IGF-I could lead to adaptations within the gut to limit the trophic response to the peptide, including receptor downregulation or upregulation of IGFBP. Unfortunately, neither IGF receptor or IGFBP expression were measured in the study. Second, the fact that des(1-3) IGF-I does not bind to low-molecular-weight IGFBP circumvents the normal physiological response to reduce the bioactivity of IGF-I by sequestering it with IGFBP. Whereas in the short term, this lack of binding to IGFBP potentiates the bioactivity of des(1-3)IGF-I by increasing its binding to the IGF receptor, in the long term, it could lead to a greater degree of receptor downregulation.

We have begun to characterize the intestinal development of piglets suckling IGF-I transgenic swine (Hartke et al., 2003). Intestinal samples were obtained from piglets throughout lactation (d 3, 7, 14, and 21 postpartum). Preliminary data suggest that, with the exception of increased mucosal mass and associated increases in protein and DNA content and digestive enzyme activity, the intestinal development of young, healthy sowreared piglets is not markedly impacted by ingestion of sow milk with elevated IGF-I concentrations (Hartke et al., 2003). These results are consistent with the hypothesis put forth by Burrin (1997). However, observed improvements in intestinal structure and digestive enzyme activity of piglets on $\mathrm{d} 21$ support the hypothesis that piglets suckling IGF-I Tg sows may have improved intestinal health and performance during the weaning transition (Hartke et al., 2003).

\section{CONCLUSIONS}

Oral administration of formula supplemented with recombinant human IGF-I to artificially reared piglets has been shown by several different laboratories to increase intestinal growth and digestive function. However, there are a number of limitations to this experimental approach that restrict application to animal production systems, including the use of an artificial rearing environment, the short duration of IGF-I administration, and the pharmacological doses used in some studies.

The development of $\mathrm{Tg}$ lines of mice and swine that overexpress IGF-I in milk has allowed for investigation of actions related to elevated concentrations of IGF-I in milk on intestinal development of normal neonates. Future studies with IGF-I transgenic animals should investigate the potential benefit of milk-borne IGF-I in compromised neonates. For example, studies conducted in experimentally induced animal models of intestinal disease or genetically modified mice have supported a therapeutic role for IGF-I in promoting recovery and repair processes in a number of gastrointestinal disorders. These disorders include damage resulting from radiation enteritis, chemotherapy, and inflammatory bowel disease (Reviewed by Howarth, 2003). Insulinlike growth factor-I augments the beneficial effects of 
limited enteral nutrition on reversing intestinal atrophy and stimulating lactase activity (Park et al., 1999). In our studies, intestinal atrophy was induced by placing piglets on total parenteral nutrition (Park et al., 1999), but intestinal atrophy is also observed in pigs during the weaning transition (McCracken et al., 1999). Improving villus morphology and mucosal mass, protein, and DNA content prior to weaning by ingestion of milk-borne IGF-I may result in better intestinal health and function. Another potential application of IGF-I is to improve intestinal structure following pathogenic injury, as has been shown for epidermal growth factor (Zijlstra et al., 1994) or transforming growth factor- $\alpha$ (Rhoads et al., 1995) following rotavirus infection in artificially reared piglets.

In conclusion, it is now feasible to use $\mathrm{Tg}$ technology for the introduction of value-added characteristics into livestock, including swine. For example, targeted mammary $\mathrm{Tg}$ overexpression of bovine $\alpha$-LA significantly improved economically important traits (e.g., milk production and piglet growth; Noble et al., 2000). Additionally, Tg livestock can be used as models to address questions pertinent to animal health and disease.

\section{ACKNOWLEDGMENTS}

The authors acknowledge the following individuals for their assistance with management of the transgenic animals, genotype screening, and sample collection: T. Abrahamson, D. Bidner, J. Cook, S. Lane, K. Marshall, C. Nafziger, and K. Ochonicky.

\section{REFERENCES}

Alexander, A. N., and H. V. Carey. 1999. Oral IGF-I enhances nutrient and electrolytes absorption in neonatal piglet intestine. Am. J. Physiol. 277:G619-G625.

Alexander, A. N., and H. V. Carey. 2001. Involvement of PI 3-kinase in IGF-I stimulation of jejunal $\mathrm{Na}^{+}-\mathrm{K}^{+}$-APTase activity and nutrient absorption. Am. J. Physiol. 277:G619-G625.

Alexander, A. N., and H. V. Carey. 2002. Insulin-like growth factorI stimulates $\mathrm{Na}^{+}$-dependent glutamine absorption in piglet enterocytes. Dig. Dis. Sci. 47:1129-1134.

Ballard, F. J., J. C. Wallace, G. L. Francis, L. C. Read, and F. M. Tomas. 1996. Des (1-3) IGF-I: a truncated form of insulin-like growth factor-I. Int. J. Biochem. Cell. Biol. 28:1085-1087.

Bleck, G. T., B. R. White, D. J. Miller, and M. B. Wheeler. 1998. Production of bovine $\alpha$-lactalbumin in the milk of transgenic pigs. J. Anim. Sci. 76:3072-3078.

Blum, J. W., and C. R. Baumrucker. 2002. Colostral and milk insulinlike growth factors and related substances: mammary gland and neonatal (intestinal and systemic) targets. Domest. Anim. Endocrinol. 23:101-110.

Brem, G., P. Hartl, U. Besenfelder, E. Wolf, N. Zinovieva, and R. Pfaller. 1994. Expression of synthetic cDNA sequences encoding human insulin-like growth factor I (IGF-I) in the mammary gland of transgenic rabbits. Gene 149:351-355.

Burrin, D. G., 1997. Is milk-borne insulin-like growth factor-I essential for neonatal development? J. Nutr. 127:975S-979S.

Burrin, D. G., T. A. Davis, S. Ebner, P. A. Schoknecht, M. L. Fiorotto, P. J. Reeds, and S. McAvoy. 1995. Nutrient-independent and nutrient-dependent factors stimulate protein synthesis in colostrum-fed newborn pigs. Pediatr. Res. 37:593-599.

Burrin, D. G., M. A. Dudley, P. J. Reeds, R. J. Shulman, S. Perkinson, and J. Rosenberger. 1994. Feeding colostrum rapidly alters enzymatic activity and the relative isoform abundance of jejunal lactase in neonatal pigs. J. Nutr. 124:2350-2357.

Burrin, D. G., M. L. Fiorotto and D. L. Hadsell. 1999. Transgenic hypersecretion of des(1-3) human insulin-like growth factor I in mouse milk has limited effects on the gastrointestinal tract of suckling pups. J. Nur. 129:51-56.

Burrin, D. G., R. J. Shulman, P. J. Reeds, T. A. Davis, and K. R. Gravitt. 1992. Porcine colostrum and milk stimulate visceral organ and skeletal muscle protein synthesis in neonatal piglets. J. Nutr. 122:1205-1213.

Burrin, D. G., B. Stoll, M. Z. Fan, M. A. Dudley, S. M. Donovan, and P. J. Reeds. 2001. Oral IGF-I alters the posttranslational processing, but not the activity of lactase-phlorizin hydrolase in formula-fed neonatal pigs. J. Nutr. 131:2235-2241.

Burrin, D. G., T. J. Wester, T. A. Davis, S. Amick, and J. P. Heath. 1996. Orally administered insulin-like growth factor-I increases intestinal mucosal growth in formula-fed neonatal pigs. Am. J. Physiol. 270:R1085-R1091.

Cohick, W. S. 1998. Role of insulin-like growth factors and their binding proteins in lactation. J. Dairy Sci. 81:1769-1777.

Donovan, S. M., J. C.-J. Chao, R. T. Zijlstra, and J. Odle. 1997. Orally administered iodinated recombinant human insulin-like growth factor-I ( $\left.{ }^{125} \mathrm{I}-\mathrm{IGF}-\mathrm{I}\right)$ is poorly absorbed by the neonatal piglets. $\mathrm{J}$. Pediatr. Gastroenterol. Nutr. 24:174-182.

Donovan, S. M., L. K. McNeil, R. Jimenez-Flores, and J. Odle. 1994 Insulin-like growth factors and IGF binding proteins in porcine serum and milk throughout lactation. Pediatr. Res. 36:159-168.

Donovan, S. M., M. H. Monaco, G. T. Bleck, J. B. Cook, M. S. Noble, W. L. Hurley, and M. B. Wheeler. 2001. Transgenic overexpression of bovine $\alpha$-lactalbumin and human insulin-like growth factor-I in porcine mammary gland. J. Dairy Sci. 84(E. Suppl.):E216-E222.

Donovan, S. M., and J. Odle. 1994. Growth factors in milk as mediators of infant development. Pages 147-167 in Annu. Rev. of Nutr. Vol. 14. R. E. Olson, D. M. Bier and D. B. McCormick, ed. Annual Reviews, Inc., Palo Alto, CA.

Dudley, M. A., D. G. Burrin, L. J. Wykes, G. Toffolo, C. Cobelli, B. L. Nichols, J. Rosenberger, F. Jahoor, and P. J. Reeds. 1998. Protein kinetics determined in vivo with a multiple-tracer, singlesample protocol: Application to lactase synthesis. Am. J. Physiol. 274:G591-G598.

Flint, D. J., E. Tonner, and G. J. Allan. 2000. Insulin-like growth factor binding proteins: IGF-dependent and -independent effects in the mammary gland. J. Mamm. Gland Biol. Neoplasia 5:65-73.

Hadsell, D. L., S. G. Bonnette, and A. V. Lee. 2002. Genetic manipulation of the IGF-I axis to regulate mammary gland development and function. J. Dairy Sci. 85:365-377.

Hadsell, D. L., N. M. Greenberg, J. M. Gligger, C. R. Baumrucker, and J. M. Rosen. 1996. Targeted overexpression of des(1-3) human insulin-like growth factor-I in transgenic mice influences mammary gland development and IGF binding protein expression. Endocrinology 137:321-330.

Hartke, J. L., M. H. Monaco, M. B. Wheeler, and S. M. Donovan. 2003. Intestinal growth and development in piglets suckling insulin like growth factor-I (IGF-I) transgenic sows. J. Dairy Sci. 86(Suppl. 1):311. (Abstr.)

Heinz-Erian, P., U. Kessler, B. Funk, P. Gais, and W. Kiess. 1991. Identification and in situ localization of the insulin-like growth factor-II/mannose-6-phosphate (IGF-II/M6P) receptor in the rat gastrointestinal tract: comparison with the IGF-I receptor. Endocrinology 129:1769-1778.

Houle, V. M., S. C. Laswell, G. G. Freund, M. A. Dudley, and S. M. Donovan. 2000. Investigation of three doses of oral insulin-like growth factor-I on jejunal lactase phlorizin hydrolase activity and gene expression and enterocyte proliferation and migration in piglets. Pediatr. Res. 48:497-503.

Houle, V. M., E. A. Schroeder, J. Odle, and S. M. Donovan. 1997. Small intestinal disaccharidase activity and ileal villus height are 
increased in piglets consuming formula containing recombinant human insulin-like growth factor-I. Pediatr. Res. 42:78-86.

Howarth, G. S. 2003. Insulin-like growth factor-I and the gastrointestinal system: therapeutic indications and safety implications. J. Nutr. 133:2109-2112.

Hwa, V., Y. Oh, and R. G. Rosenfeld. 1999. The insulin-like growth factor-binding protein (IGFBP) family. Endocr. Rev. 20:761-787.

Lee, C. Y., F. W. Bazer, and F. A. Simmen. 1993. Expression of components of the insulin-like growth factor system in pig mammary glands and serum during pregnancy and pseudopregnancy: effects of oestrogen. J. Endocrinol. 137:473-483.

LeRoith, D., S. Neuenschwander, T. L. Wood, and L. Hennighausen. 1995. Insulin-like growth factor-I and insulin-like growth factor binding protein-3 inhibit involution of the mammary gland following lactation: studies in transgenic mice. Prog. Growth Factor Res. 6:433-436.

MacDonald, R. 1999. The role of insulin-like growth factors in small intestinal cell growth and development. Horm. Metab. Res. 31:103-113.

McCracken, B. A., M. E. Spurlock, M. A. Roos, F. A. Zuckermann, and H. R. Gaskins. 1999. Weaning anorexia may contribute to local inflammation in the piglet small intestine. J. Nutr. 129:613-619.

Monaco, M. H., W. L. Hurley, M. B. Wheeler, and S. M. Donovan. 2003. Insulin-like growth factor-I (IGF-I) modulates the process of mammary apoptosis after weaning in IGF-I transgenic pigs. J. Dairy Sci. 86(Suppl. 1):301. (Abstr.)

Morgan, C. J., A. G. P. Coutts, M. C. McFadyen, T. P. King, and D. Kelly. 1996. Characterization of IGF-I receptors in the porcine small intestine during postnatal development. J. Nutr. Biochem. 7:339-347.

Neuenschwander, S., A. Schwartz, T. L. Wood, C. T. Roberts, Jr., L. Henninghausen, and D. LeRoith. 1996. Involution of lactating mouse mammary gland is inhibited by the IGF-I system in a transgenic mouse model. J. Clin. Invest. 97:2225-2232.

Noble, M. S., S. Rodriguez-Zas, J. B. Cook, G. T. Bleck, W. L. Hurley, and M. B. Wheeler. 2002. Lactational performance of first-parity transgenic gilts expressing bovine $\alpha$-lactalbumin in their milk. J Anim Sci. 80:1090-1096.

Oh, Y., H. L. Mller, E. K. Neely, G. Lamson, and R. G. Rosenfeld. 1993. New concepts in insulin-like growth factor receptor physiology. Growth Reg. 3:113-123.

Park, Y. K., M. H. Monaco, and S. M. Donovan. 1999. Orally administered insulin-like growth factor-I augments intestinal disaccharidase activity in piglets receiving total parenteral nutrition. J. Pediatr. Gastroent. Nutr. 29:198-206.

Prosser, C. G., I. R. Fleet, A. N. Corps, E. R. Froesch, and R. B. Heap. 1990. Increase in milk secretion and mammary blood flow by intra-arterial infusion of insulin-like growth factor-I into the mammary gland of the goat. J. Endocrinol. 126:437-443.
Rao, R. K., A. F. Philipps, C. S. Williams, D. M. McCracken, and O. Koldovsky. 1998. Luminal stability of insulin-like growth factors I and II in developing rat gastrointestinal tract. J. Pediatr. Gastroenterol. Nutr. 26:179-185.

Rosfjord, E. C., and R. B. Dickson. 1999. Growth factors, apoptosis and survival of mammary epithelial cells. J. Mam. Gland Biol. Neoplasia 4:229-237.

Rhoads, J. M., M. H. Ulshen, E. O. Keku, W. Chen, H. M. Kandil, J. P. Woodard, S. C. Liu, C. R. Fuller, H. L. Leary Jr., and J. G. Lecce. 1995. Oral transforming growth factor- $\alpha$ enhances jejunal mucosal recover and electrical resistance in piglet rotavirus enteritis. Pediatr. Res. 38:173-181.

Shamay, A., N. Cohen, M. Niwa, and A. Gertler. 1988. Effects of insulin-like growth factor I on deoxyribonucleic acid synthesis and galactopoiesis in bovine undifferentiated and lactating mammary tissue. Endocrinology 123:804-809.

Shennan, D. B. 1998. Mammary gland membrane transport systems. J. Mamm. Gland Biol. Neoplasia 3:247-258.

Tavakkol, A., F. A. Simmen, and R. C. M. Simmen. 1988. Porcine insulin-like growth factor-I (pIGF-I): complementary deoxyribonucleic acid cloning and uterine expression of messenger ribonucleic acid encoding evolutionarily conserved IGF-I peptides. Mol. Endocrinol. 2:674-681.

Widdowson, E. M., E. V. Colombo, and C. A. Artavanis. 1976. Changes in the organs of pigs in response to feeding for the first $24 \mathrm{~h}$ after birth. II. The digestive tract. Biol. Neonate 28:272-281.

Winder, S. J., A. Turvey, and I. A. Forsyth. 1989. Stimulation of DNA synthesis in cultures of ovine mammary epithelial cells by insulin and insulin-like growth factors. J. Endocrinol. 123:319-326.

Wolf, E., P. M. Jehle, M. M Weber, H. Sauerwein, A. Daxenberger, B. H. Brier, U. Besenfelder, L. Frenyo, and G. Brem. 1997. Human insulin-like growth factor I (IGF-I) produced in the mammary glands of transgenic rabbits: yield, receptor binding, mitogenic activity, and effects of IGF-I binding proteins. Endocrinology 138:307-313.

Xian, C. J., C. A. Shoubridge, and L. C. Read. 1995. Degradation of IGF-I in the adult rat gastrointestinal tract is limited by a specific antiserum or the dietary protein casein. J. Endocrinol. $146: 215-225$.

Xu, R.-J., D. J. Mellor, M. J. Birtles, B. H. Breier, and P. D. Gluckman. 1994. Effects of oral IGF-I or IGF-II on digestive organ growth in newborn piglets. Biol. Neonate 66:280-287.

Zijlstra, R. T., J. Odle, W. F. Hall, B. W. Petschow, H. B. Gelberg, and R. E. Litov. 1994. Effect of orally administered epidermal growth factor on intestinal recovery of neonatal pigs infected with rotavirus. J. Pediatr. Gastroenterol. Nutr. 19:382-390.

Zinovieva, N., C. Lassnig, K. Schams, U. Besenfelder, E. Wolf, S. Müller, L. Frenyo, J. Seregi, M. Müller, and G. Brem. 1998. Stable production of human human insulin-like growth factor I (IGF-I) in the milk of hemi- and homozygous transgenic rabbits over several generations. Transgenic Res. 7:437-447. 